\title{
Teachers' Engagement in and Coping with Emergency Remote Instruction during COVID-19-Induced School Closures: A Multinational Contextual Perspective
}

\author{
Magdalena Jelińska and Michał B. Paradowski \\ Institute of Applied Linguistics, University of Warsaw
}

\begin{abstract}
The COVID-19 pandemic required educators and learners to shift to emergency remote instruction, often with little prior notice. To understand how teachers managed the transition, from April to September 2020 we surveyed nearly 1,500 instructors from 118 countries. Using cluster analysis, we have detected two readily distinguishable groups of instructors: a group who were more engaged in remote instruction and coping with the challenges of online teaching more successfully, and another group who scored lower on both of these fronts. We compare the two groups in terms of their sociodemographic characteristics, and assess the relationship between each sociodemographic marker and teachers' engagement and coping. Overall, our results suggest that teachers were most engaged and coped best with the transition when they had prior experience with remote instruction, worked in the higher education sector, and used real-time synchronous modalities. We also find non-trivial results regarding teachers' gender, years of teaching experience, and their country's level of economic development, while observing no relationship between teachers' age and their levels of engagement or coping. The detection of the contextual effects underscores the importance of large multisite research.
\end{abstract}

Keywords: COVID-19, emergency remote teaching, remote delivery, on-line teaching, synchronous/asynchronous delivery, school closure, teacher experience, engagement, coping, global survey, contextual variables

Jelińska, M., \& Paradowski, M.B. (2021). Teachers' engagement in and coping with emergency remote instruction during COVID-19-induced school closures: A multinational contextual perspective. Online Learning Journal, 25(1), 303-328.

https://doi.org/10.24059/olj.v25i1.2492 


\section{Teachers' Engagement in and Coping with Emergency Remote Instruction during COVID-19-Induced School Closures: A Multinational Contextual Perspective}

In the spring of 2020, school across the world closed in the effort to reduce the transmission of the COVID-19 virus, throwing educational systems into disarray, disrupting the schooling of over $80 \%$ of the students worldwide, and upending the lives of teachers and their students (International Labour Organization, 2020; UNESCO, 2020). As institutions scrambled to ensure continuity of learning, educators and learners found themselves shifting to emergency remote instruction, usually with little time given for preparation.

To understand how teachers managed the transition, from April until September 2020 we carried out a custom-made multinational survey study involving participants from 118 countries, exploring 441 interlocking factors that potentially influenced the patterns of the stakeholders' adaptation to online provision during school closures. In this paper, we zoom in on two of the key constructs differentiating the better- and the worse-coping instructors: teachers' engagement in remote teaching and teacher coping with remote instruction. We present and discuss the findings against the backdrop of one individual and three contextual variables which were identified as significant moderating predictors: gender, education level handled, mode of delivery (synchronous versus asynchronous), and the economic status of the respondent's country.

\section{Review of Relevant Literature}

Scholarship is still nascent regarding teachers' adaptation to emergency remote instruction during the COVID-19-induced school closures. Several studies have focused on institutional or system-level factors that influence teacher transitions, while others have concentrated on individual teachers' personal and interpersonal contexts.

In terms of institutional or system-level factors, the University of Houston (2020) published a report summarizing the faculty's perceptions regarding the transition to a remote teaching model, revealing significant variation in terms of the implementation of technology tools and of the mode of instruction. While the transition was claimed to have worked under the circumstances, only a small fraction of the respondents did not experience some kind of obstacles, including concerns about the conducting of final assessment. A survey by Quality Matters and Eduventures ${ }^{\circledR}$ Research (Legon et al., 2020) carried out among chief online officers at colleges and universities reported that while most believed the pivot to remote teaching to be a logistic success, most simultaneously admitted at least a measure of difficulty, citing low levels of faculty and student preparedness (in $75 \%$ and $62 \%$ of cases, respectively). Better infrastructure had generally been available at schools with significant prior experience with online learning, while regional private universities - which attract students who choose small classes and close contact with faculty-reported the most negative student reactions. A report published by Ohio State University (Jaggars et al., 2020) discovered among others that faculty who taught their courses in real time rated online teaching challenges less negatively than those who prerecorded their lectures or used a different asynchronous delivery format. A survey deployed by Indiana University's eLearning Research and Practice Lab (2020) found that two thirds of the instructors felt disconnected from their students and that it was more difficult to teach after the school shuttered, while three quarters of the students felt they had lost touch with their IU community; a similar number declared it took them more effort to complete their course assignments after the transition. Paradowski and Jelińska (under review) showed how teachers' psychological overload during this time was mediated by the 
education level handled and access to resources. Nuere and de Miguel (2020), following an observation of universities in Spain during the pandemic, came to the conclusions that institutions which had been used to conducting online classes had minimal problems working under new conditions, and that the quality of the process was strongly affected by the quality of online teaching tools. Bensaid and Brahimi (2021) likewise attributed the successful maintenance of the learning cycle in higher education institutions in the Gulf to their already established distance education, swift administration and policy steps, and access to resources. Similarly, Tiejun (2020) claimed that due to prior preparation, education in Chinese colleges and universities did not suffer in the course of the outbreak. Reimers and Schleicher (2020) identified the most salient education needs during the pandemic, basing on survey responses from 98 different countries. These findings reveal a complex landscape of institutional and contextual influences on the effectiveness of emergency remote teaching.

In terms of instructors' personal adjustment, Jelińska and Paradowski analyzed the impact of forced remote teaching on college and university instructors' well-being, revealing for instance the importance of maintaining productivity alongside work-life synergy (under review), as well as the way teachers' professional adaptation to the new circumstances influenced their perception of how their students were coping with the novel situation (under revision). Watermeyer et al. (2020) carried out a survey of academic teachers' reactions to the move to online delivery and found that the majority of the respondents felt confident or strongly confident in their ability to facilitate online teaching and assessment, and considered their institutions to be supportive in enabling the move to online delivery. MacIntyre, Gregersen and Mercer (2020) investigated the correlations between approach and avoidant coping strategies and positive and negative psychological outcomes among an international sample of language teachers during the conversion to online instruction. Lapada et al.'s (2020) exploration of teachers' opinions on their schools' readiness and response to the challenges of distance education in the Philippines revealed that facility to adapt to distance education was strongly correlated with the length of teaching experience as well as geographic location. These studies offer some insights into how handling of the situation may be affected by individual teacher characteristics.

However, scholarship is still lacking on the specific factors influencing teachers' and learners' coping with the switch to remote instruction, and the relationships between these factors. Moreover, the vast majority of the available studies look at single countries, tend to focus on only one educational stage (e.g., either $\mathrm{K}-12$ or higher education, but not both), and only on one mode of delivery (real-time or asynchronous; many of the studies also focus on "remote learning" in general collating responses regarding both modes without ever differentiating between them), absent a comparative-contrastive perspective. To fill these gaps, we launched a survey covering all levels of education across a variety of countries and designed to disentangle synchronous from asynchronous modes of remote delivery. Our comprehensive online survey was devised to explore what circumstances, behaviors, attitudes, and psychological traits made it easier to deal with the new reality, what challenges the respondents had been facing, and what helped them and their well-being.

The research questions addressed in this contribution are as follows:

RQ1: Can one detect distinct subgroups of educators differentiated by their coping with the transition to emergency remote instruction?

RQ2: If distinct teacher cohorts can be isolated, what characterizes each group? 
RQ3: What are the patterns of educators' engagement in distance teaching vis-à-vis contextual variables?

RQ4: What are the contextual patters of teachers' coping with online instruction? In particular, how do the contextual factors of the educational stage handled, mode of online delivery, and country level of development influence the observed trends?

\section{Methods}

Survey data collection was carried out with a custom-made questionnaire set up on a commercial survey software platform (in order to reach respondents in countries where solutions such as Google Forms cannot be accessed without a VPN). A criterion for taking the survey was transitioning from regular face-to-face classes to online teaching as part of the response to the COVID-19 epidemic, as the focus was on the shift to emergency remote teaching (as opposed to continuation of pre-planned and carefully designed online learning that had also existed before the epidemic; see Hodges et al., 2020).

The questionnaire was active from late April until the end of September 2020 and recruitment was based on a snowball sampling procedure. The survey was announced through several channels: distributed through the mailing lists and websites of professional teacher associations, via the researchers' direct personal contacts, through thematic groups and pages on social media, and on an electronic grade book platform used by 7,300 schools in Poland. The protocol had received the approval of the authors' Institutional Review Board.

\section{Materials}

At the outset of the emergency transition to remote learning, it was unclear which circumstances, behaviors, attitudes, or psychological traits would be most important to teachers' management of the transition. Accordingly, the survey incorporated a wide and complex array of measures and included a total of 441 question items. Apart from sociodemographic information, the questions concerned the circumstances surrounding the participants' transition to remote instruction, their personal experiences, behaviors, attitudes, feelings, physical and mental health, and their personality traits - factors considered relevant to the adaptation. With the exception of a battery of psychological testing instruments, questions concerning participants' circumstances, behaviors, and attitudes were custom designed especially for the context of the study. While one could fall back on a few existing scales (e.g., Brief-COPE; Carver, 1997), we felt we needed items that were more relevant to the specific, unprecedented scenario of emergency remote teaching, both to better represent this novel situation, and to be more relatable to the participants. The list of items was inspired by five weeks of discussions with fellow instructors, exchanges on dedicated groups on social media platforms, and numerous articles appearing on the topic in both general and specialized press. The resultant list was ultimately reviewed by volunteers in the pilot study.

This analysis focuses on 19 items which were originally designed to understand how instructors adapted their courses to remote learning and how they felt about that adaptation, which were each measured on a six-point Likert scale ranging from "Completely disagree" to "Completely agree." For a full list of items, see Appendix Table 1. In addition, we focus on the following sociodemographic factors: teachers' age, gender, work location (country), type of educational institution represented, years of professional experience, and mode of online teaching (synchronous vs. asynchronous). 


\section{Analysis}

Our analysis consisted of four distinct steps: (a) an exploratory factor analysis to understand the constructs underlying our 19 Likert-scale items, which revealed the constructs of coping and engagement; (b) a cluster analysis to understand whether teachers fell into easilydistinguishable patterns or groupings on the two dimensions, followed by a descriptive analysis of those clusters; (c) an examination of whether teachers with different sociodemographic characteristics differed from one another in terms of coping and engagement; and (d) a regression predicting teachers' engagement based on their coping and sociodemographic characteristics. Below, we discuss each of these four steps in more detail.

First, we conducted an exploratory factor analysis (EFA) on the 19 Likert scale items, using standardized varimax rotation. EFA is particularly useful and commonly applied in developing measurement instruments that reflect latent dimensions or constructs which are represented by observed variables (Fabrigar et al., 1999). Each such variable is highly correlated with only one factor. The Keiser-Meyer-Olkin (KMO) measure of sampling adequacy was .838 and Bartlett's test of sphericity indicated that the interitem correlations were significant at the $p<.001$ level. Internal consistency among the items was satisfactory for both factors with Cronbach's alpha values above .70. The EFA resulted in two factors: engagement in remote teaching and coping with remote instruction (Appendix Table 1 shows the loadings for each item on the two factors). Six items had relatively low loadings on both factors and were dropped from further analysis. The final engagement scale consisted of 7 items assessing the extent to which educators get involved in this mode of instruction, their activities related to conducting classes such as syllabus modifications, alterations to the grading scheme, as well as attitudes toward online teaching (Cronbach's $\alpha=0.72$, McDonald's $\omega_{\mathrm{h}}=0.75$, Guttman's $\lambda_{6}=0.71$, Raykov's $\rho=0.76$ ). The coping scale consisted of 6 items assessing teachers' perceptions of overcoming difficulties such as technical issues and their own ability to use new technologies to prepare and conduct lessons (Cronbach's $\alpha=0.78$, McDonald's $\omega_{\mathrm{h}}=0.80$, Guttman's $\lambda_{6} \&$ Raykov's $\rho=0.76$ ). To create each scale, after exploratory factor analysis all negatively formulated items were reversed in order for higher scores to indicate higher levels of engagement and coping. Reverse-worded items were used in this context in order to eliminate socially desirable answers and consequently avoid the response-set bias (Kreitchmann et al., 2019; Suarez-Alvarez et al., 2018; van Sonderen, Sanderman, \& Coyne, 2013).

Second, we performed a cluster analysis to better understand the roles of the component items and sociodemographic variables in teachers' coping with emergency transition to remote teaching (Kaufman \& Rousseeuw, 2005). Instead of identifying categories on the basis of prior, often arbitrary classifications, cluster analysis allows determining categories in a dataset based on actual observed cases (Crowther et al., 2021). Detection of subgroups of educators distinguishable by their patterns of engagement and coping with the transition to the novel situation was performed first by agglomerative hierarchical clustering (HCA) with Ward's linkage in order to identify the optimal number of subgroups, followed by a $k$-means cluster analysis on normalized mean values of the relevant constructs. The former technique is one of the most frequently applied methods to identify the optimal number of clusters (King, 2015, p. 29). Based on the results of the agglomerative hierarchical clustering, a non-hierarchical clustering analysis was subsequently conducted with the $k$-means method, which allows characterizing the pre-identified groups. Computationally, this method is an ANOVA "in reverse" in that it evaluates the between-cluster variability against the within-cluster variability. The degree to which the respective dimensions 
discriminate between the groups are then revealed by their difference in means on each dimension and the magnitude of the $F$ values. Given the two classes distinguished (better- and worse-coping teachers), the key statistically significant differences between the groups were determined using ANOVA $F$ and $\chi^{2}$ tests.

Third, in order to explore whether teachers with different sociodemographic characteristics differed from one another in terms of coping and engagement, we used ANOVA and $t$-tests to compare each construct (engagement and coping) between school type/level, country classification, age, gender, previous remote teaching experience, and mode of online delivery. Finally, to predict teachers' engagement based on their coping and sociodemographic characteristics, we used multivariate linear regressions with forward selection.

\section{Respondent demographic profile}

At the time of writing this paper (late August 2020), the survey discussed here had collected answers from 4,968 teachers ${ }^{1}$, with 1,487 (30\%) completing all the required questions. The answers of participants who abandoned the survey without completing all required questions are not included in this analysis in order to avoid artifacts. The respondents were resident in 118 countries (Figure and Table 1). $8.6 \%$ were teaching in a state that was not their home country.

\section{Figure 1}

\section{Locations of the Respondents ${ }^{2}$}

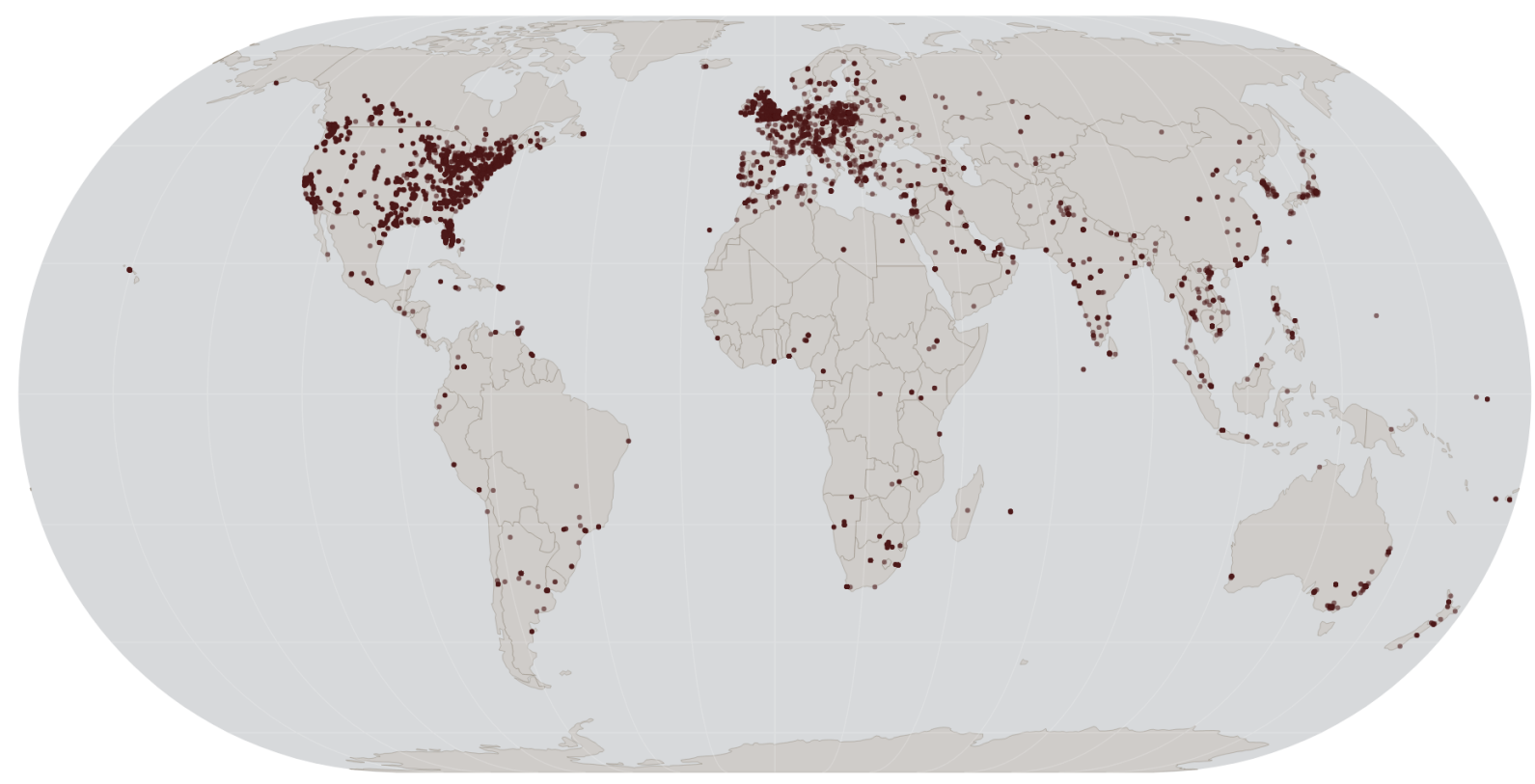

\footnotetext{
${ }^{1}$ The data analyzed in this paper form part of a much larger project (https://schoolclosure.ils.uw.edu.pl/) that also included university instructors in language-related fields as well as corresponding student and language learner populations. These latter data, as well as data collected during and after the mid-2020 semester break, are omitted from the analyses herein. For reasons of space and thematic coherence, we also exclude a presentation and discussion of other contextual findings as well as those from the battery of psychological tests that concluded the questionnaire.

${ }^{2}$ In a negligible number of cases, the locations may be inaccurate if the questionnaire respondents were using a VPN or IP spoofing.
} 


\section{Table 1}

Respondent Locations $(\mathrm{N}=1,487)$

\begin{tabular}{lcc}
\hline Continents and countries & Frequency (n) & Percent (\%) \\
\hline USA & 588 & 39.5 \\
Poland & 248 & 16.7 \\
UK & 122 & 8.2 \\
Canada & 102 & 6.9 \\
Australia & 44 & 3.0 \\
Rest of Europe & 170 & 11.4 \\
Asia & 147 & 9.9 \\
South America & 27 & 1.8 \\
Africa & 25 & 1.7 \\
Rest of North America & 14 & 0.9 \\
\hline
\end{tabular}

To better understand the potential influence of the socioeconomic conditions of working in these countries, they were classified as economically developed or developing on the basis of the World Bank classification (based on gross national income per capita). Overall, $90.05 \%$ of the teachers participating in this study work in developed countries, while the remaining $9.95 \%$ work in developing countries.

The gender distribution among the participants was $86 \%$ female and $13 \%$ male, with less than $1 \%$ ( 9 respondents) identifying as nonbinary/not listed. The age span was 22 to 74 , with the mean and median 44; the teaching experience ranged from 0 to 49 years, with the mean 13.7 and median 12 years. Eighteen percent had previous experience with remote teaching, such as elearning, blended courses, MOOCS, or webinars. The age range of the respondents as well as the reported length of teaching experience are presented in Tables 2 and 3, respectively. The teachers' degrees as well as subjects taught covered a full spectrum of disciplines (notably languages, science, math, history, arts, design, music, geography, biology, chemistry, health, psychology, literacy, and special education). Seventy percent of the teachers indicated that they had a fairly wide range of freedom in deciding on the topic and content of the courses they taught. ${ }^{3}$ Most teachers transitioned their courses into a real-time "synchronous" online modality (58\%) while the remainder transitioned into an "asynchronous" modality, which was characterized by less directed methods such as sharing materials and/or uploading prerecorded content.

\section{Table 2}

Participant Age Groups $(\mathrm{N}=1,487)$

\begin{tabular}{lrr}
\hline Age group (years) & Frequency (n) & Percent (\%) \\
\hline Under 35 & 314 & 21 \\
$36-45$ & 455 & 31 \\
$46-55$ & 413 & 28 \\
Over 55 & 274 & 18 \\
Not reported & 31 & 2 \\
\hline
\end{tabular}

\footnotetext{
${ }^{3}$ The extent of this liberty failed to correlate with success in transitioning to distance learning or lack thereof.
} 


\section{Table 3}

Respondents' Teaching Experience ( $\mathrm{N}=1,487)$

\begin{tabular}{lrr}
\hline Experience (in years) & Frequency (n) & Percent (\%) \\
\hline$<5$ & 293 & 19.7 \\
$6-10$ & 280 & 18.8 \\
$11-15$ & 256 & 17.2 \\
$16-20$ & 206 & 13.9 \\
$21-25$ & 212 & 14.3 \\
Over 25 & 233 & 15.7 \\
Not reported & 7 & 0.5 \\
\hline
\end{tabular}

The schools at which respondents taught included all sectors from $\mathrm{K}-12$ through higher education. Based on the outcome of a Kruskal-Wallis test (as the non-parametric equivalent of a one-way ANOVA), kindergarten and elementary school were analyzed as one category, "K-5," while secondary/high and vocational schools were represented as one category, "high school." As shown in Table 4, the most common levels taught were high school (30\%) and K-5 (23\%). Across the schools, $74 \%$ were state schools, $19 \%$ private, $4 \%$ religious schools, and $3 \%$ run by an NGO or foundation.

\section{Table 4}

Education Institutions Represented by the Teachers $(\mathrm{N}=1,487)$

\begin{tabular}{lrr}
\hline School type / level & Frequency (n) & Percent (\%) \\
\hline K-5 & 347 & 23 \\
middle school & 182 & 12 \\
high school (including vocational school) & 446 & 30 \\
higher education & 374 & 25 \\
private tuition/self-employed/freelance/other & 138 & 9 \\
\hline
\end{tabular}

\section{Cluster Analysis}

\section{Results}

As shown in Figure 2, the agglomerative hierarchical clustering with Ward's linkage indicated that teachers could be classified into two clusters: those who were more engaged and coped better with remote teaching $(N=853$ educators, or $57 \%)$, and those who were less engaged and did not cope as well $(N=597$, or $43 \%)$.

The horizontal axis measures the distance between the clusters, whereas the vertical axis represents the participants and clusters. To describe the nature and meaning of the two clusters, we compared between them in terms of their sociodemographic characteristics, as well as using non-hierarchical $k$-means cluster analysis. 


\section{Figure 2.}

Dendrogram Demonstrating Two Clusters.

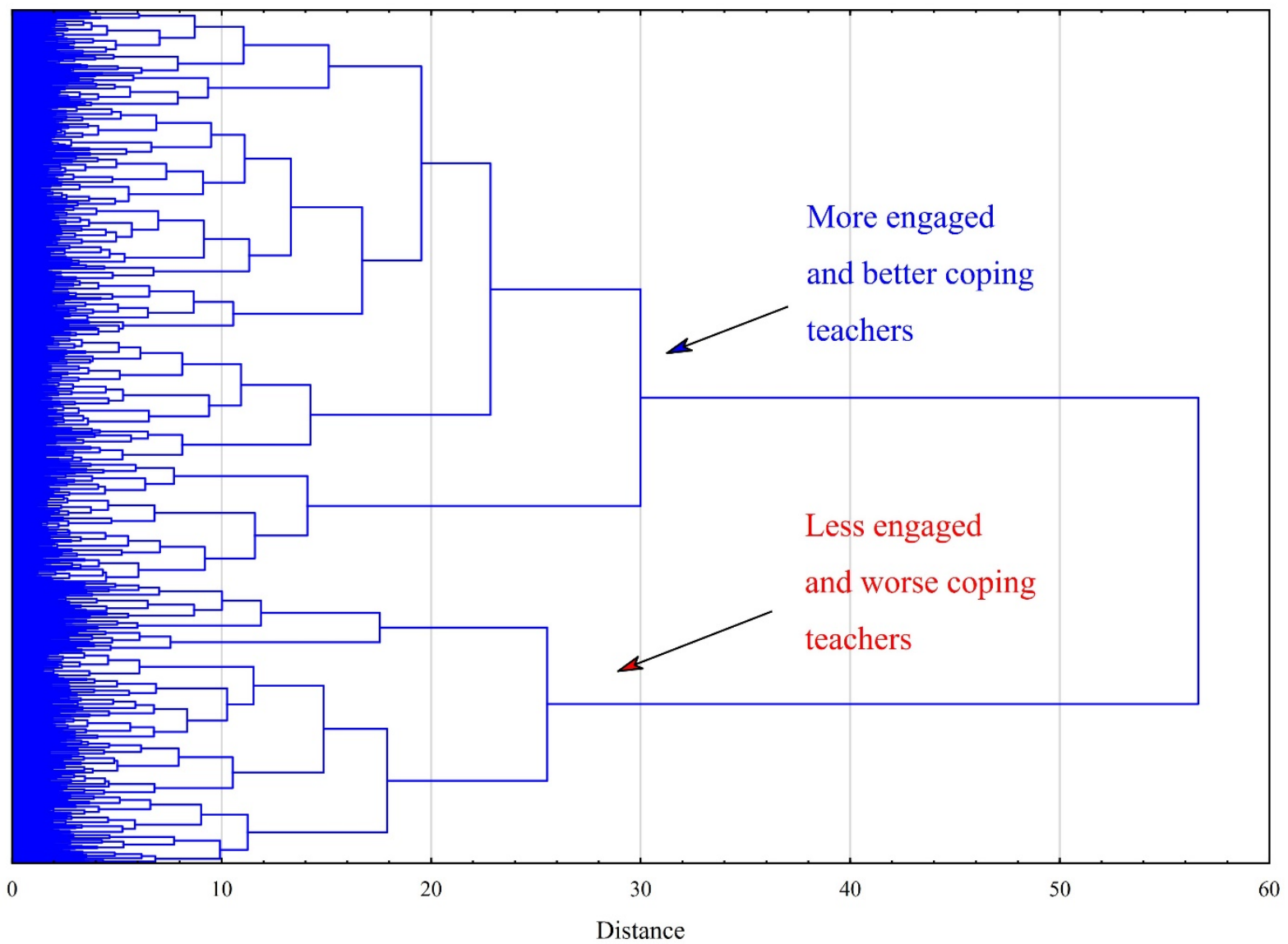

Comparisons between the two clusters in terms of their demographic characteristics revealed that they differed substantially in terms of whether they taught synchronously or asynchronously $\left(\chi^{2}=674.36[1], p<.001\right)$, their school type $\left(\chi^{2}=237.22[4], p<.001\right)$, prior experience with remote teaching $\left(\chi^{2}=39.32[1], p<.001\right)$, their overall years of teaching experience $\left(\chi^{2}=89.16[56], p<.001\right)$, and to a lesser extent in terms of gender $\left(\chi^{2}=12.69\right.$ [2], $\left.p<.001\right)$ and the country they work in (developed vs. developing; $\chi^{2}=4.15[1], p<.001$ ). The two groups did not differ, however, in terms of age $\left(\chi^{2}=63.14[3], p=.138\right)$.

The cluster of more engaged and better-coping instructors tended to work in high schools $(35 \%)$ or higher education $(32 \%)$ and to teach remotely in real time using a synchronous modality $(86 \%)$, with most (77\%) declaring no previous experience with remote teaching. Teachers in this cluster had a mean age of 47 and a mean 10 years of teaching experience; most were female (84\%) and worked in developed countries (89\%). The cluster of relatively less engaged and more poorly coping teachers tended to teach in $\mathrm{K}-5$ (41\%), middle $(17 \%)$, or high schools $(24 \%)$. Very few taught their remote classes synchronously in real time (18\%), and they were even less likely than the first cluster to have previous experience with remote teaching $(11 \%)$. Compared with teachers in the first cluster, the teachers in this cluster were even more likely to be female $(90 \%)$ and to work in developed countries (92\%). They had a higher mean of 20 years of teaching experience, despite being slightly younger than the first cluster, with a mean age of 40 . This seems due to a differential distribution in age between the two groups: while the more-engaged cluster was 
relatively evenly distributed across age categories (24\% under $35,16 \%$ aged $35-44,35 \%$ aged $45-$ $54,17 \%$ over 55), the less-engaged cluster was more likely to be in their late thirties or early forties (26\% under age $35,54 \%$ aged $35-44,16 \%$ aged $45-54,16 \%$ over 55 ). A full description of each cluster is available in Appendix Table 2.

The non-hierarchical $k$-means cluster analysis revealed that the two clusters of teachers differed on every item in the engagement and coping scales, as shown in Table 5. For every item, teachers in the "more engaged and better coping" group responded more positively on that item (including being less likely to agree with negatively valenced items).

\section{Table 5}

ANOVA F test for Quantitative Variables Distinguishing the Two Groups of Teachers

\begin{tabular}{|c|c|c|c|c|c|}
\hline № & Item short label & $\begin{array}{c}\text { M(SE) Cluster } 1 \\
\text { (more engaged } \\
\text { and better-coping } \\
\text { teachers) }\end{array}$ & $\begin{array}{c}\text { M(SE) Cluster } 2 \\
\text { (less engaged and } \\
\text { worse-coping } \\
\text { teachers) }\end{array}$ & $\boldsymbol{F}$ & $\eta_{p^{2}}$ \\
\hline 1 & perceived engagement & $4.38(.05)$ & $3.06(.06)$ & $316.35 * *$ & .18 \\
\hline 2 & RT unexpectedly difficult & $3.24(.05)$ & $4.20(.06)$ & $197.77 * *$ & .12 \\
\hline 3 & preference for $\mathrm{F} 2 \mathrm{~F}$ format & $4.57(.05)$ & $5.32(.04)$ & $89.62 * *$ & .06 \\
\hline 4 & modified lesson plans & $4.86(.05)$ & $5.45(.04)$ & $77.66^{* *}$ & .05 \\
\hline 5 & eased grading & $4.19(.05)$ & $5.00(.06)$ & $154.05 * *$ & .10 \\
\hline 6 & modified class content & $3.96(.05)$ & $5.04(.05)$ & $150.09 * *$ & .10 \\
\hline 7 & reduced possibility to meet students' needs & $4.15(.05)$ & $5.14(.05)$ & $207.46^{* *}$ & .13 \\
\hline 8 & initial confidence in RT ability & $4.42(.05)$ & $3.67(.06)$ & $131.07 * *$ & .08 \\
\hline 9 & tech support & $4.16(.06)$ & $4.05(.07)$ & $11.44 * *$ & .008 \\
\hline 10 & feeling left behind & $2.35(.05)$ & $3.14(.07)$ & $162.37 * *$ & .10 \\
\hline 11 & tech issues & $3.59(.05)$ & $4.11(.06)$ & $86.72^{* *}$ & .06 \\
\hline 12 & lack of hardware curtailing RT potential & $2.49(.05)$ & $3.33(.07)$ & $142.27 * *$ & .10 \\
\hline 13 & cybersecurity anxiety & $2.98(.06)$ & $3.52(.07)$ & $112.95 * *$ & .07 \\
\hline
\end{tabular}

$* * p<.001$ 


\section{Table 6}

Mean Scores of Teachers' Engagement and Teacher Coping vis-à-vis predictor variables $(\mathrm{N}=1,487)$.

\begin{tabular}{|c|c|c|c|c|}
\hline & $\begin{array}{r}\text { Engagement } \\
\text { Mean (SE) }\end{array}$ & $\begin{array}{r}\text { Difference } \\
\text { among groups } \\
{[95 \% \mathrm{CI}]} \\
\end{array}$ & $\begin{array}{r}\text { Coping } \\
\text { Mean (SE) }\end{array}$ & $\begin{array}{r}\text { Difference } \\
\text { among groups } \\
{[95 \% \mathrm{CI}]}\end{array}$ \\
\hline School Type / Level & & $\begin{array}{l}1482)=40.61^{* * *} \\
=.10[.07 ; .12]\end{array}$ & & $\begin{array}{r}F(4,1482)=9.31 * * \\
\eta_{p}^{2}=.02[.01 ; .04]\end{array}$ \\
\hline $\mathrm{K}-5^{\text {aefg }}$ & $2.69(.04)$ & {$[2.62 ; 2.76]$} & $3.66(.05)$ & {$[3.55 ; 3.77]$} \\
\hline Middle school $^{\text {af }}$ & $2.61(.05)$ & {$[2.51 ; 2.70]$} & $3.88(.07)$ & {$[3.74 ; 4.03]$} \\
\hline High school / vocational ${ }^{\mathrm{a}}$ & $2.78(.03)$ & {$[2.71 ; 2.84]$} & $2.71(.05)$ & {$[3.86 ; 4.05]$} \\
\hline Higher education & $3.17(.04)$ & {$[3.09 ; 3.24]$} & $4.08(.05)$ & {$[3.98 ; 4.17]$} \\
\hline Other ${ }^{\text {bcd }}$ & $3.26(.07)$ & {$[3.12 ; 3.40]$} & $4.08(.08)$ & {$[3.92 ; 4.23]$} \\
\hline Country Classification & & $\begin{array}{l}t(1485)=3.59 * \\
=.31[.14 ; .48]\end{array}$ & & $\begin{array}{r}t(1485)=-.94 \\
d=.08[-.09 ; .25]\end{array}$ \\
\hline Developed & $2.86(.02)$ & {$[2.82 ; 2.90]$} & $3.93(.03)$ & {$[3.87 ; 3.98]$} \\
\hline Developing & $3.09(.06)$ & {$[2.98 ; 3.20]$} & $3.84(.08)$ & {$[3.69 ; 4.00]$} \\
\hline Age & & $\begin{array}{l}F(3,1482)=.57 \\
=.001[0 ; .004]\end{array}$ & & $\begin{array}{r}F(3,1452)=.51 \\
\eta_{\mathrm{p}}{ }^{2}=.001[0 ; .003]\end{array}$ \\
\hline Under 35 & $2.92(.04)$ & {$[2.84 ; 3.00]$} & $3.96(.05)$ & {$[3.85 ; 4.06]$} \\
\hline $35-44$ & $2.85(.04)$ & {$[2.78 ; 2.92]$} & $3.94(.05)$ & {$[3.85 ; 4.03]$} \\
\hline $45-54$ & $2.88(.04)$ & {$[2.81 ; 2.95]$} & $3.87(.05)$ & {$[3.77 ; 3.97]$} \\
\hline Over 55 & $2.88(.05)$ & {$[2.79 ; 2.97]$} & $3.90(.07)$ & {$[3.77 ; 4.04]$} \\
\hline Gender & & $\begin{array}{l}484)=13.71^{* * *} \\
=.02[.008 ; .03]\end{array}$ & & $\begin{array}{l}F(2,1484)=2.95 \\
\eta_{p^{2}}=.004[0 ; .01]\end{array}$ \\
\hline Female $^{\mathrm{h}}$ & $2.84(.02)$ & {$[2.80 ; 2.88]$} & $3.89(.03)$ & {$[3.84 ; 3.95]$} \\
\hline Male $^{\mathrm{h}}$ & $3.13(.06)$ & {$[3.01 ; 3.24]$} & $4.08(.07)$ & {$[3.95 ; 4.21]$} \\
\hline Not listed/Nonbinary & $3.21(.18)$ & {$[2.78 ; 3.63]$} & $3.98(.41)$ & {$[3.03 ; 4.93]$} \\
\hline $\begin{array}{l}\text { Prior Remote Teaching } \\
\text { Experience }\end{array}$ & & $\begin{array}{l}(1485)=-7.8^{* * *} \\
=.52[.39 ; .66]\end{array}$ & & $\begin{array}{r}t(1485)=-8.0 * * \\
d=.54[.40 ; .67]\end{array}$ \\
\hline No & $2.81(.02)$ & {$[2.77 ; 2.85]$} & $3.82(.03)$ & {$[3.77 ; 3.88]$} \\
\hline Yes & $3.19(.05)$ & {$[3.09 ; 3.29]$} & $4.35(.05)$ & {$[4.25 ; 4.46]$} \\
\hline Course Mode & & $\begin{array}{l}485)=-11.6^{* *} \\
=.61[.50 ; .71]\end{array}$ & & $\begin{array}{r}t(1485)=-6.2 * * \\
d=.33[.22 ; .43]\end{array}$ \\
\hline Synchronous & 3.06 & {$[3.01 ; 3.11]$} & 4.05 & {$[3.99 ; 4.12]$} \\
\hline Asynchronous & 2.63 & {$[2.58 ; 2.68]$} & 3.73 & {$[3.65 ; 3.81]$} \\
\hline
\end{tabular}

${ }^{*} p<.05,{ }^{* *} p<.001$

Note. Effect sizes for the independent-samples $t$-test are determined with Cohen's $d$, whereas in ANOVA as partial eta-squared $\eta_{\mathrm{p}}{ }^{2}$. Superscripts indicate significant pairwise differences based on Tukey's post-hoc test $(p<.05)$ [for engagement: $\mathrm{a}=$ higher education, $\mathrm{b}=$ high school, $\mathrm{c}=$ middle school, $\mathrm{d}=\mathrm{K}-5$, for coping: $\mathrm{e}=$ higher education, $\mathrm{f}=$ high school, $\mathrm{g}=$ other, $\mathrm{h}=$ gender] . 


\section{Sociodemographic Differences in Engagement and Coping}

In addition to investigating sociodemographic differences between clusters, we also explored how the sociodemographic groups differed in terms of the coping and engagement scales. The assumption of normality was checked subjectively via a visual inspection of Q-Q and P-P plots and objectively using the Shapiro-Wilk test. Homogeneity of variance was assessed visually using a Q-Q scatterplot and objectively with Levene's test. Table 6 provides the mean of engagement and coping for each sociodemographic subgroup, an overall significance test comparing among the subgroups ( $F$ or $t)$ and the related effect size $\left(\eta_{\mathrm{p}}{ }^{2}\right.$ or $\left.d\right)$, as well as the $95 \%$ confidence intervals for each subgroup's mean.

In order to better verify the nature of the variables, we also calculated $\chi^{2}$ values, which indicate meaningful relationships between teaching engagement and country classification $\left(\chi^{2}=\right.$ 5487.62, $p<.001)$ and course mode $\left(\chi^{2}=4188.71, p<.001\right)$, as well as between teacher coping and country classification $\left(\chi^{2}=13146.81, p<.001\right)$, previous remote teaching experience $\left(\chi^{2}=\right.$ $3246.83, p<.001)$, and course type $\left(\chi^{2}=8822.94, p<.001\right)$.

In terms of school type or level, university instructors assessed their engagement in remote teaching significantly higher than teachers from $\mathrm{K}-5$, middle, and high schools. It seems worth noting that the second most-engaged group of instructors were teachers outside of the $\mathrm{K}-\mathrm{HE}$ track. They also differed significantly in the perception of the difficulties to overcome during remote teaching, experiencing them to a lesser extent compared with the $\mathrm{K}-5$ teacher group. The difference in coping was also significant between higher education instructors and all the other teacher groups, with the former reporting to cope better.

Interestingly, it transpires that teachers in developed countries felt significantly less engaged in remote instruction than their counterparts from developing countries. On the other hand, no significant difference was observed in this relation in coping with difficulties during remote classes.

Experience in dealing with setbacks, individual perception, cognitive abilities and other functions vary across the life span. However, in the context investigated age did not seem to play a role.

Even though there is a great gender disproportion in our sample dominated by women, the results show that female teachers reported to be significantly less engaged in their online work compared with their male colleagues. However, there were no significant differences between these groups in terms of coping with technological issues.

Previous teaching experience seems to be important for a smoother and faster adaptation to the new circumstances. As expected, teachers who had prior experience with remote instruction are significantly more engaged in their work as well as deal better with difficulties during lessons than teachers who shifted to remote teaching without having any experience in this mode of working.

In terms of online course delivery mode, instructors who taught their classes in real time were significantly more engaged in teaching compared with those who used asynchronous modes of delivery. Interestingly, educators working synchronously also reported significantly fewer difficulties in using new technologies during the lessons. 


\section{Predicting Teacher Engagement}

To better understand the relative contribution of the above variables to teachers' engagement in remote teaching, a multivariate linear regression analysis was conducted using STATISTICA 13's module of General Regression Models, which method permits the inclusion of continuous and categorical predictors. The linearity assumption was tested on the basis of a visual inspection of scatterplots. Histograms indicated that the variables and the residuals of the regression were normally distributed. Lack of multicollinearity was verified by computing a matrix of Pearson's bivariate correlations among all independent variables, with the correlation coefficient values below .80. The assumption of homoscedasticity was also met, verified with a scatterplot of residuals versus predicted values. As shown in Table 7, model predictors included the overall coping score as well as key sociodemographic variables. For the predictor of education type / level, each group is compared against the reference category of "Other."

\section{Table 7}

Multivariate Linear Regressions Built with ANCOVA (Forward Selection) for Variables Predicting Teachers' Engagement

\begin{tabular}{|c|c|c|c|c|c|c|c|}
\hline & step & $b$ & $\beta$ & SE & $t$ & \multicolumn{2}{|c|}{$95 \%$ CI } \\
\hline intercept & & 2.14 & & 0.12 & 18.55 & 1.91 & 2.37 \\
\hline coping & 1 & $0.24 *$ & 0.32 & 0.02 & 13.76 & 0.21 & 0.27 \\
\hline course mode: synchronous & 2 & $0.12 *$ & 0.17 & 0.02 & 6.88 & 0.16 & 0.09 \\
\hline education type / level: & 3 & & & & & & \\
\hline $\mathrm{K}-5$ & & $-0.09 *$ & -0.07 & 0.03 & -2.68 & -0.16 & -0.02 \\
\hline middle school & & $-0.24 *$ & -0.15 & 0.04 & -5.75 & -0.32 & -0.16 \\
\hline high school & & $-0.08 *$ & -0.07 & 0.03 & -2.70 & -0.14 & -0.02 \\
\hline higher education & & $0.15^{*}$ & 0.11 & 0.03 & 4.34 & 0.08 & 0.21 \\
\hline country classification: developed & 4 & $-0.07 *$ & -0.06 & 0.03 & -2.61 & -0.13 & -0.02 \\
\hline prior remote teaching experience: no & 5 & $-0.06^{*}$ & -0.06 & 0.02 & -2.73 & -0.11 & -0.02 \\
\hline gender: female & 6 & $-0.13 *$ & -0.06 & 0.09 & -1.41 & -0.30 & 0.05 \\
\hline age & - & & & & & & \\
\hline years of professional experience & - & & & & & & \\
\hline
\end{tabular}

The proposed linear model proved to be statistically significant $\left(F_{10,1439}=51.19 ; p<.001\right)$ and explains approximately $25.7 \%$ of the total variance of teacher engagement. The multivariate linear regression reveals that the most important predictor of teachers' engagement in online classes is coping with remote teaching difficulties $(\beta=.32, t=13.76, p<.001)$. Next, teacher engagement also depends on the mode of instruction (higher levels for the synchronous vs. asynchronous modality; $\beta=.17, t=-6.88, p<.001)$ as well as education level handled (K-5: $\beta=-.07, t=-2.68, p<.001$; middle school: $\beta=-.15, t=-5.75, p<.001$; high school: $\beta=-.07$, $t=-2.70, p<.001$; higher education: $\beta=.11, t=4.34, p<.001)$. To a lesser extent, engagement is also predicted by lack of previous experience with online teaching $(\beta=-.06, t=-2.73, p<.001)$ as well as working in a developed country $(\beta=-.06, t=-2.61, p<.001)$ and gender $(\beta=-.06, t=-1.41, p<.001)$. After controlling for coping and the other sociodemographic characteristics, teachers' age and years of professional experience were not significant predictors of engagement in remote teaching and were dropped from the model. 


\section{Discussion}

The situation learners and teachers suddenly found themselves in upon the announcement of school closures is, with a few historic exceptions (which involved school classes taught over the radio or television), unprecedented in terms of both scale and duration. Emergency transition to remote teaching significantly affected teachers' coping with their work and general functioning. Given that distance learning is likely to increasingly become part and parcel of mainstream education (Bozkurt, 2019), it is worthwhile identifying factors that influence teacher engagement and coping in order to offer successful policy, administration, and training solutions. Our results suggest that key factors which predicted instructor engagement in the emergency transition were the type or level of school, asynchronous or synchronous modality, and the instructors' level of coping. We also discovered weaker but potentially interesting predictors of gender and the country's level of economic development. Below, we discuss these results and their potential implications.

\section{Level or Type of School at which the Instructors Taught}

The education levels at which the instruction is carried out appear to be a factor that markedly differentiates the better- and the worse-coping groups. The abrupt shift to remote instruction appeared to be a particularly difficult experience for educators overseeing lower education levels. Not only did this group feel unprepared for this mode of teaching, they were also more disengaged in the process. This finding is congruent with the observation by Hvas and Aller (2020) about the greater difficulty of the remote teaching of nursery and primary school pupils. The lower coping and engagement emerging from the responses of teachers instructing the youngest age groups may be due to several factors. One is that young learners are the most reliant on assistance, scaffolding and support in their scholastic process (Zaccoletti et al., 2020), and parents and other guardians may not always be around during the pandemic to help with technology, establish schedules, ensure that the children stay on task and submit their work in a timely manner (Reilly, 2020; Szabo et al., 2020), and help out in other ways necessary (even older and more mature learners - including university students - may need assistance and guidance in their autonomous, self-directed learning; Hung et al., 2010; Paradowski, 2014, p. 8; 2015, pp. 43ff.; Owusu-Fordjour, Koomson, \& Hanson, 2020; Reimers \& Schleicher, 2020, p. 21). Older students with more developed self-regulation strategies are better able to take control over their learning (Herold, 2017). Smaller children are moreover more likely to miss their grandparents during this time (Dalton et al., 2020) and to be affected by contextual factors (Sameroff, 2010), and less likely to have a computer, tablet or smartphone to access remote classes in real time. It is also much more difficult for them to have to spend long hours stationarily in front of the screen. Additionally, many teachers from lower education levels have students with special needs, for whom it is especially difficult to spend hours focused on classes while sitting in front of the computer (Susana Sotillo, personal communication, October 2, 2020). Also, unlike higher education instructors, K-12 teachers are often responsible for contact tracing on top of their usual commitments. Hvas and Aller (2020) add that it is easier to stay at home for the older, secondary school students, and that the reopening of schools for the youngest children provides relief to parents and allows them to continue working.

However, it should be noted that reluctance to teach remotely cannot be limited to educators teaching at lower education levels. Ebner et al. (2020) mentioned that a large group of university professors in Germany stated that they could not teach online. Our findings indicate that such patterns cannot be dismissed by simply invoking the factor of age. Still, college and university 
instructors tend to be the readiest to switch to distance teaching, likely due to the availability of the facilities, equipment, infrastructure, and institutional IT support, and the tradition of innovation in education (Li \& Wang, 2020). For instance, where their home situation does not provide the optimal environment for online instruction, academics in most scenarios can use their offices and/or classrooms. In contrast, depending on the location, some basic education schools may lack the facilities and training even if they are located in urban areas (Lapada et al., 2020). Institutional training and backing as well as social support had been found to determine the successful adoption of e-learning in the past (Singh, Naz, \& Narayan, 2017). Higher education may also have endured more crises in the past (Giridharan, 2020, p. 108).

The group that experienced the second-highest level of engagement in remote instruction and reported experiencing the fewest problems were teachers outside of the $\mathrm{K}-\mathrm{HE}$ track. One speculative explanation for this interesting finding may be that, having had to navigate a volatile private/freelance tuition market, these instructors had worked out robust coping strategies and resilient, dependable, and perhaps more personally engaged contacts with their students. Alternatively, without a permanent employment contract or with only a precarious one, these teachers may have been more invested in maintaining their source of income. The finding certainly merits closer inspection.

The detection of the contextual effect of the education level handled underscores the importance of large multisite research (MSR; Moranski \& Ziegler, 2020), as the impact of the level of education handled had failed to reach significance in smaller, national studies (e.g., Lapada et al., 2020, p. 138).

\section{Online Modality}

The better coping and engagement in real-time classes is consistent with the findings by Jaggars and colleagues (2020, p. 25). The prevalence of asynchronous communication in the worse-coping cluster likely contributed to barriers in teacher-students interaction and the difficulty of seeing students' reactions, which could have translated into problems with evaluation of learners' activity. This is congruent with other studies revealing problems establishing communication with students, with the monitoring of responses, and with providing tailored thoughtful feedback as some of the major challenges identified by teachers (Iwai, 2020; Lapada et al., 2020, p. 135; Reimers \& Schleicher, 2020, p. 15). As reminded by Durden (2020), in the massive turn to online learning we must bear in mind that it will begin to be a viable educational model only when it manages to maximally approximate the affordances of the live classroom environment-which among others means "preferably a full or partly synchronous experience." In the words of Genone (2020), "one of the most important lessons of the forced adoption of remote instruction may turn out to be the realization that pedagogy, rather than technology, is the key ingredient for delivering effective education online." One recommendation might also be for academics to create an online presence to make students feel they are part of a community (McMurtrie, 2020).

Given that the better-coping teachers were mainly teaching remotely in real time while instructors who coped worse with the transition (and were doing more asynchronous instruction) were primarily teaching at more junior education levels, epidemic situation permitting, this might be an argument for reopening kindergartens and primary schools, given children's need for the development of social competences (Jarynowski et al., in press). 


\section{Coping}

The findings also showed that initial convictions and confidence regarding distance teaching heavily bear on actual performance. This emphasizes the importance of the provision of proper (re-)training ahead of instruction, as well as of institutional backing in general-educators who felt more supported by their school fared better. Lack of training and school tech support had been found to induce higher technostress among teachers (Joo et al., 2016; Li \& Wang, 2020). The provision of adequate teacher training was also listed as one of five major moves in the Chinese education policy of “Suspending Classes Without Stopping Learning” ““停课不停教、停课不停 学"; Zhang et al., 2020; see also Huang et al., 2020). Tiejun (2020) also highlighted the importance of prior preparation. Thus, technological training ought to become permanent part-and-parcel of teachers' pre-service, on-the-job, and just-in-time (Reimers \& Schleicher, 2020, pp. 5, 8) professional development to help them keep abreast of the developments.

\section{Gender and Type of Country}

Our results suggest that women experienced more challenges in adjusting to the emergency transition. Considering that women constitute a vast majority of the participants taking part in this research, the results should be treated with caution. Still, one potential explanation for the higher engagement in male teachers could be their not only stereotypical greater involvement in technology (among friends and colleagues from different continents, social media posts of instructional set-ups with multiple screens and studio-quality microphones have predominantly come from men's profiles - although men may also be more inclined to share updates about their devices), or a tendency to overestimate own capacity. Both possibilities would be congruent with the findings of Alemany-Arrebola and colleagues' (2020) study carried out among 427 students in Spain, where men indicated the highest perception of self-efficacy, while women had higher scores in trait and state anxiety. Emerging studies from the pandemic generally tend to indicate higher levels of COVID-generated stress in women (Cao et al., 2020; Qiu et al., 2020; Taylor et al., 2020), who perceived the emergency as more serious than males did (Commodari \& La Rosa, 2020; Li et al., 2020), in line with earlier research demonstrating that women tend to have a higher perception of risk (e.g., Harris et al., 2006). Females are also consistently found to be more anxious about privacy and risky online behavior (Milne et al., 2009; Mohamed \& Ahmad, 2012; Hajli \& Lin, 2016; Chou \& Sun, 2017). Another viable hypothesis might be a lower number of other timeconsuming commitments such as childcare, looking after relatives, and (typically) household and domestic chores.

Another intriguing result suggested a higher level of engagement among teachers from developing countries. Time constraints have not yet permitted us to analyze the responses to the open-ended questions, but one speculative explanation might be that teachers in these settings manage to establish a deeper connection with their students, for whom continuity of education is particularly crucial. Another possibility might be that educators in developing countries are significantly more dependent on their job for their subsistence. The finding certainly merits further investigation. Meanwhile, it is estimated that in 2021, 67 low- and lower-middle income countries will only get vaccines for a tenth of their population (Oxfam International, 2020), while those which have managed to secure the jab may be being charged much steeper rates (e.g., South Africa reportedly having been quoted nearly 2.5 times more than EU member states; AFP, 2021). 


\section{Conclusion}

Teacher coping significantly affects all sides of the education process. For instance, an analysis of U.S. and Canadian students' tweets regarding the transition to an online class format performed by EDUCAUSE Review revealed that students appreciate faculty who remain positive, comfortable, and calm, and want their instructors to be at ease with technology. While the pandemic has taken its toll on our lives and well-being, there is hope the experience may bring some positive developments and insights for post-pandemic education. Institutions should consider not only ad hoc, but also longer-term adjustments to support teachers and students. Given that distance education via online learning, including MOOCs, had already been a growing trend pre-pandemic (Xu \& Jaggars, 2014; Tarone, 2015; Jaggars, 2018; Marciniak et al., 2018), in the future teachers may use online delivery to complement their face-to-face teaching (Kim, 2020). As the World Bank observed, "the COVID-19 crisis might retrospectively be considered as an opportunity to strategically revamp systems and prepare for the challenges to come" (2020a, p. 17; see also Brown \& Salmi, 2020). This can best be done with support for all stakeholders, advancement of teachers' and students' digital skills, and adequate investment in infrastructure and the ecosystem.

The current study, by deliberate design, only solicited responses from educators who had reacted to the new necessity by moving their classes online. One of the obvious limitations, shared by most large-scale surveys (national censuses notwithstanding), is the issue of participant selfselection. Unlike in "captive" groups common in many education scenarios, participation in this study was completely voluntary. Given that on many occasions the questionnaire took upwards of 45 minutes to complete, the respondents were already motivated, could relate to the topic, and had the spare time and technology 4 to comfortably fill out the survey. This means a limit on the representativeness and generalization potential of the data and resultant findings (see Brown, 2001, p. 85).

This article presents only a slice of the teachers' vantage point; this will be complemented with later publications on other relevant aspects of educators' adaptation to the transition (Jelińska \& Paradowski, under review; under revision; Paradowski \& Jelińska, under review), as well as analyses of students' perspectives. Also, we have not yet investigated the relationship between the timing of the responses relative to the date of the shift to remote instruction; this will be calculated in forthcoming longitudinal analyses comparing early and late reactions from the same respondents.

\section{Author Note}

Magdalena Jelińska(D) 0000-0002-1520-0836

Michał B. Paradowski(iD) 0000-0002-0710-3075

\footnotetext{
${ }^{4}$ E.g., one respondent from Syria could not complete the survey due to their slow VPN connection.
} 


\section{Acknowledgments}

We want to extend our words of sincere gratitude to the volunteers who generously completed and provided feedback on the pilot versions of the survey, all the participants who took the time to fill in the questionnaire despite other commitments, as well as friends, colleagues, professional associations, the Librus platform, and administrators of the thematic groups on social media for publicizing and/or enabling to share information about the survey. We also thank Shanna S. Jaggars for the detailed suggestions and careful editing, and Andrzej Jarynowski, Anindya Bhattacharya, Anjela Taneja, Bronson Hui, Frederick Edward Fabella, Georgia Irre, Grzegorz Śpiewak, Luke Plonsky, Marilu Raňosa Madrunio, Miguel Ángel Cruz Pérez, Mogamat Faadiel Arnold, Philip Hiver, Shaine Christian Ocampo, Susana Sotillo, Vasistha Bhargavi, and the anonymous reviewers for valuable constructive feedback on earlier drafts of this manuscript.

The authors are supported by SONATA-BIS grant № 2016/22/E/HS2/00034 from the National Science Centre of Poland. MBP also acknowledges support from COST Actions 15109 COSTNET, 15130 SAREP and 18232 MAT-DYN-NET. All the usual disclaimers apply. 


\section{References}

AFP (2021, Jan. 22). https://www.msn.com/en-sg/news/world/safrica-to-pay-25-times-more-than-eufor-virus-vaccine/ar-BB1cYe5M

Alemany-Arrebola, I., Rojas-Ruiz, G., Granda-Vera, J., \& Custodio Mingorance-Estrada, Á. (2020). Influence of COVID-19 on the perception of academic self-efficacy, state anxiety, and trait anxiety in college students. Frontiers in Psychology. https://doi.org/10.3389/fpsyg.2020.570017

Bensaid, B., \& Brahimi, T. (2021). Coping with COVID-19: Higher education in the GCC Countries. In A. Visvizi, M. D. Lytras \& N. F. Aljohani (Eds.), Research and Innovation Forum 2020: Disruptive Technologies in Times of Change (pp. 137-153). Springer. https://doi.org/10.1007/978-3-030-62066-0_12

Bozkurt, A. (2019). From distance education to open and distance learning: A holistic evaluation of history, definitions, and theories. In S. Sisman-Ugur \& G. Kurubacak (Eds.), Handbook of Research on Learning in the Age of Transhumanism (pp. 252-273). IGI Global. https://doi.org/10.4018/978-1-5225-8431-5.ch016

Brown, C., \& Salmi, J. (2020, Apr. 8-9). Readying for the future: COVID-19, higher ed, and fairness. Medium. https://medium.com/todays-students-tomorrow-s-talent/readying-for-the-futurecovid-19-higher-ed-and-fairness-f7eeb814c0b8

Brown, J. D. (2001). Using surveys in language programs. Cambridge University Press.

Cao, W., Fang, Z., Hou, G., Han, M., Xu, X., Dong, J., et al. (2020). The psychological impact of the COVID-19 epidemic on college students in China. Psychiatry Research, 287, 112934. https://doi.org/10.1016/j.psychres.2020.112934

Carver, C. S. (1997). You want to measure coping but your protocol's too long: Consider the brief COPE. International Journal of Behavioral Medicine, 4(1), 92-100. https://doi.org/10.1207/s15327558ijbm0401_6

Chou, H.-L. \& Sun, J. C.-Y. (2017). The moderating roles of gender and social norms on the relationship between protection motivation and risky online behavior among in-service teachers. Computers \& Education, 112, 83-96. https://doi.org/10.1016/j.compedu.2017.05.003

Commodari, E. \& La Rosa, V. L. (2020). Adolescents in quarantine during COVID-19 pandemic in Italy: Perceived health risk, beliefs, psychological experiences and expectations for the future. Frontiers in Psychology, 11, 559951. https://doi.org/10.3389/fpsyg.2020.559951

Crowther, D., Kim, S., Lee, J., Lim, J., \& Loewen, S. (2021). Methodological synthesis of cluster analysis in second language research. Language Learning. https://doi.org10.1111/lang.12428

Dalton, L., Rapa, E. \& Stein, A. (2020). Protecting the psychological health of children through effective communication about COVID-19. The Lancet Child \& Adolescent Health, 4(5), 346-347. https://doi.org/10.1016/S2352-4642(20)30097-3

Durden, W. G. (2020, Apr. 8). Turning the tide on online learning. Inside Higher Ed. https://www.insidehighered.com/views/2020/04/08/online-learning-can-only-be-viable-if-itoffers-certain-connection-points 
Ebner, M., Schön, S., Braun, C., Ebner, M., Grigoriadis, Y., Haas, M., Leitner, P. \& Taraghi, B. (2020). COVID-19 epidemic as e-learning boost? Chronological development and effects at an Austrian university against the background of the concept of "e-learning readiness." Future Internet, 12(6), 94. https://doi.org/10.3390/fi12060094

eLearning Research and Practice Lab, Indiana University Pervasive Technology Institute (2020). Going remote: Actionable insights from Indiana University's transition to remote instruction due to COVID-19. https://drive.google.com/file/d/1pN3ICAn7uJp3nQ6CpsEjJ7ZBgE0axoin/

Fabrigar, L. R., Wegener, D. T., MacCallum, R. C., Strahan, E. J. (1999). Evaluating the use of exploratory factor analysis in psychological research. Psychological Methods, 4, 272-299. https://doi.org/10.1037/1082-989X.4.3.272

Genone, J. (2020, Apr. 23). The hard part of online teaching is not the "online" part. Medium. https://medium.com/edtechx360/the-hard-part-of-online-teaching-is-not-the-online-part65e556a6da3a

Giridharan, B. (2020). Engaging with students and faculties online in the era of the corona virus pandemic: a higher education perspective. Journal of Humanities and Social Sciences Research, 2(S): 103-110. https://horizon-jhssr.com/view-issue.php?id=27

Hajli, N. \& Lin, X. (2016). Exploring the security of information sharing on social networking sites: The role of perceived control of information. Journal of Business Ethics, 133(1), 111-123. https://doi.org/10.1007/s10551-014-2346-X

Harris, C. R., Jenkins, M. \& Glaser, D. (2006). Gender differences in risk assessment: Why do women take fewer risks than men? Judgment and Decision Making, 1(1), 48-63. http://journal.sjdm.org/06016/jdm06016.htm

Herold, B. (2017, Feb. 5). Technology in education: An overview. Education Week. https://www.edweek.org/technology/technology-in-education-an-overview/2016/02

Hodges, C., Moore, S., Lockee, B., Trust, T. \& Bond, A. (2020, Mar. 27). The difference between emergency remote teaching and online learning. EDUCAUSE Review. https://er.educause.edu/articles/2020/3/the-difference-between-emergency-remote-teachingand-online-learning

Huang, R. H., Liu, D. J., Tlili, A., Yang, J. F., Wang, H. H., et al. (2020, Mar. 15). Handbook on facilitating flexible learning during educational disruption: The Chinese experience in maintaining undisrupted learning in COVID-19 outbreak. Smart Learning Institute of Beijing Normal University/UNESCO International Research and Training Centre for Rural Education. https://iite.unesco.org/wp-content/uploads/2020/03/Handbook-on-FacilitatingFlexible-Learning-in-COVID-19-Outbreak-SLIBNU_V2.0_20200324.pdf

Hung, M.-L., Chou, C., Chen, C.-H. \& Own, Z.-Y. (2010). Learner readiness for online learning: Scale development and student perceptions. Computers \& Education, 55(3), 1080-1090. https://doi.org/10.1016/j.compedu.2010.05.004

Hvas, L. \& Aller, E. (2020, Apr. 24). Back to school: Preparing and managing reopening of schools COVID-19 education webinar \#6. UNESCO. https://en.unesco.org/events/back-schoolpreparing-and-managing-reopening-schools-covid-19-education-webinar-6

International Labour Organization (2020). COVID-19 and the education sector. https://www.ilo.org/sector/Resources/publications/WCMS_742025/lang--en/index.htm 
Iwai, Y. (2020, Mar. 13). Online learning during the COVID-19 pandemic. What do we gain and what do we lose when classrooms go virtual?

https://blogs.scientificamerican.com/observations/online-learning-during-the-covid-19pandemic/

Jaggars, S. S. (2018). Online learning in the community college context. In M. G. Moore \& W.C. Diehl (Eds.), Handbook of distance education, 4th ed. (pp. 445-455). Routledge. https://doi.org/10.4324/9781315296135

Jaggars, S. S., Rivera, M. D., Hance, E. K. \& Heckler, A. (2020). Ohio State COVID-19 teaching \& learning survey. The Ohio State University. https://hdl.handle.net/1811/92047

Jarynowski, A., Paradowski, M. B. \& Czopek, K. (in press). Keep your friends close: Jak interakcje między uczniami pomagają w przyswajaniu języka obcego. Implikacje dla doby pandemii.

Jelińska, M. \& Paradowski, M. B. (under review). The impact of demographics, life and work circumstances on college and university instructors' well-being during quaranteaching. Frontiers in Psychology.

Jelińska, M. \& Paradowski, M. B. (under revision). Teachers' perception of student coping with emergency remote instruction during the COVID-19 pandemic: The relative impact of educator demographics and professional adaptation and adjustment. Frontiers in Psychology.

Joo, Y. J., Lim, K. Y., \& Kim, N. H. (2016). The effects of secondary teachers' technostress on the intention to use technology in South Korea. Computers \& Education, 95, 114-122. https://doi.org/10.1016/j.compedu.2015.12.004

Kaufman, L. \& Rousseeuw, P. J. (2005). Finding groups in data: An introduction to cluster analysis. Wiley.

Kim, J. (2020, Apr. 1). Teaching and learning after COVID-19. Inside Higher Ed. https://www.insidehighered.com/digital-learning/blogs/learning-innovation/teaching-andlearning-after-covid-19

King, R.S. (2015). Cluster analysis and data mining: An introduction. Mercury Learning and Information.

Kreitchmann, R. S., Abad, F. J., Ponsoda, V., Nieto, M. D. \& Morillo, D (2019). Controlling for response biases in self-report scales: Forced-choice vs. psychometric modeling of Likert items. Frontiers in Psychology, 10, 2309. https://doi.org/10.3389/fpsyg.2019.02309

Lapada, A. A., Miguel, F. F., Robledo, D. A. R. \& Alam, Z. F. (2020). Teachers' Covid-19 awareness, distance learning education experiences and perceptions towards institutional readiness and challenges. International Journal of Learning, Teaching and Educational Research, 19(6), 127-144. https://doi.org/10.26803/ijlter.19.6.8

Legon, R., Garrett, R., Fredericksen, E. E. \& Simunich, B. (2020). CHLOE 5: The Pivot to Remote Teaching in Spring 2020 and Its Impact. The Changing Landscape of Online Education, 2020. Quality Matters. https://www.qualitymatters.org/qa-resources/resource-center/articlesresources/CHLOE-5-report-2020

Li, X., Lv, S., Liu, L., Chen, R., Chen, J., Liang, S., Tang, S. \& Zhao, J. (2020). COVID-19 in Guangdong: Immediate perceptions and psychological impact on 304,167 college students. Frontiers in Psychology, 11, 2024. https://doi.org/10.3389/fpsyg.2020.02024 
Li, L. \& Wang, X. (2020). Technostress inhibitors and creators and their impacts on university teachers' work performance in higher education. Cognition, Technology \& Work. https://doi.org/10.1007/s10111-020-00625-0

MacIntyre, P. D., Gregersen, T. \& Mercer, S. (2020). Language teachers' coping strategies during the COVID-19 conversion to online teaching: Correlations with stress, wellbeing and negative emotions. System, 94, 102352. https://doi.org/10.1016/j.system.2020.102352

Marciniak, M., Paradowski, M. B. \& Zhu, M. (2018). Different forms of assessment in a pronunciation MOOC-Reliability and pedagogical implications. In A. Palalas, H. Norman \& P. Pawluk (Eds.), Blended learning in the age of social change and innovation: Proceedings of the 3rd World Conference on Blended Learning (pp. 34-41). International Association for Blended Learning.

McMurtrie, B. (2020, Apr. 9). How to reconnect with students and strengthen your remote course. The Chronicle of Higher Education. https://www.chronicle.com/newsletter/teaching/202004-09

Milne, G. R., Labrecque, L. I. \& Cromer, C. (2009). Toward an understanding of the online consumer's risky behavior and protection practices. Journal of Consumer Affairs, 43(3), 449473. https://doi.org/10.1111/j.1745-6606.2009.01148.x

Mitchell, C. (2020, Mar. 17). English-learners may be left behind as remote learning becomes "new normal.” Education Week, http://blogs.edweek.org/edweek/learning-thelanguage/2020/03/coronavirus_english_learners_digital_divide.html

Mohamed, N. \& Ahmad, I. H. (2012). Information privacy concerns, antecedents and privacy measure use in social networking sites: Evidence from Malaysia. Computers in Human Behavior, 28(6), 2366-2375. https://doi.org/10.1016/j.chb.2012.07.008

Moorhouse, B. J. (2020). Adaptations to a face-to-face initial teacher education course "forced' online due to the COVID-19 pandemic. Journal of Education for Teaching, 46(4), 609611 https://doi.org/10.1080/02607476.2020.1755205

Moranski, K., \& Ziegler, N. (2021). A case for multisite second language acquisition research: Challenges, risks, and rewards. Language Learning, 71(1), 204-242. https://doi.org/10.1111/lang.12434

Murphy, M. P. A. (2020). COVID-19 and emergency eLearning: Consequences of the securitization of higher education for post-pandemic pedagogy. Contemporary Security Policy, 41(3), 492505. https://doi.org/10.1080/13523260.2020.1761749

Nuere, S., \& de Miguel, L. (2020). The digital/technological connection with COVID-19: An unprecedented challenge in university teaching. Technology, Knowledge and Learning. https://doi.org/10.1007/s10758-020-09454-6

Oxfam International (2020, Dec. 9). Campaigners warn that 9 out of 10 people in poor countries are set to miss out on COVID-19 vaccine next year. https:/www.oxfam.org/en/pressreleases/campaigners-warn-9-out-10-people-poor-countries-are-set-miss-out-covid-19vaccine

Owusu-Fordjour, C., Koomson, C. K. \& Hanson, D. (2020). The impact of COVID-19 on learningThe perspective of the Ghanaian student. European Journal of Education Studies, 7(3), 88100. https://doi.org/10.46827/ejes.v0i0.3000 
Paradowski, M. B. (2014). Classrooms in the cloud or castles in the air? IATEFL Voices, 239, 8-10.

Paradowski, M. B. (2015). Holes in SOLEs: Re-examining the role of EdTech and "minimally invasive education" in foreign language learning and teaching. English Lingua Journal, 1(1), $37-60$.

Paradowski, M. B., \& Jelińska, M. (under review). The impact of disparities and awareness thereof on educators' psychological overload during emergency remote teaching: The mediating roles of logistics, perception of student coping and appraisal of situational impact. Teachers and Teaching.

Qiu, J., Shen, B., Zhao, M., Wang, Z., Xie, B. \& Xu, Y. (2020). A nationwide survey of psychological distress among Chinese people in the COVID-19 epidemic: Implications and policy recommendations. General Psychiatry, 33(2), e100213.

https://doi.org/10.1136/gpsych-2020-100213

Reilly, K. (2020, Mar. 15). as schools close amid coronavirus concerns, the digital divide leaves some students behind. Time. https://time.com/5803355/school-closures-coronavirus-internetaccess/

Reimers, F. M., \& Schleicher, A. (2020). A framework to guide an education response to the COVID-19 pandemic of 2020. OECD. https://read.oecd-ilibrary.org/view/?ref=126_126988t631xosohs\&title=A-framework-to-guide-an-education-response-tothe-Covid-19-Pandemicof- 2020

Sameroff, A. (2010). A unified theory of development: a dialectic integration of nature and nurture. Child Development, 81(1), 6-22. https://doi.org/10.1111/j.1467-8624.2009.01378.x

Singh, G., Naz, R., \& Narayan, J. J. (2017). Investigating critical factors for adoption of e-learning in the South Pacific region. Investigating critical factors for adoption of e-learning in the South Pacific Region. International Journal of Instructional Technology and Distance Learning, 14(2), 41-58. https://www.itdl.org/Journal/Feb_17/Feb17.pdf

Suárez-Alvarez, J., Pedrosa, I., Lozano, L. M., García-Cueto, E., Cuesta M., \& Muñiz, J. (2019). Using reversed items in Likert scales: A questionable practice. Psicothema, 30(2), 149-158. https://doi.org/10.7334/psicothema2018.33

Szabo, T. G., Richling, S., Embry, D. D., Biglan, A. \& Wilson, K. G. (2020). From helpless to hero: Promoting values-based behavior and positive family interaction in the midst of COVID-19. Behavior Analysis in Practice, 13, 568-576. https://doi.org/10.1007/s40617-020-00431-0

Taylor, S., Landry, C. A., Paluszek, M. M., Fergus, T. A., McKay, D. \& Asmundsoon, G. J. G. (2020). COVID stress syndrome: Concept, structure, and correlates. Depression \& Anxiety, 37(8), 706-714. https://doi.org/10.1002/da.23071

Thatcher, A., Zhang, M., Todoroski, H., Chau, A., Wang, J., \& Liang, G. (2020). Predicting the impact of COVID-19 on Australian universities. Journal of Risk and Financial Management, 13(9) 188. https://doi.org/10.3390/jrfm13090188

Tiejun, Z. (2020). Empirical research on the application of online teaching in Chinese colleges and universities under the situation of novel coronavirus pneumonia prevention and control. International Journal of Emerging Technologies in Learning, 15(11), 119-136. https://doi.org/10.3991/IJET.V15I11.13935

UNESCO. (2020). COVID-19 impact on education. https://en.unesco.org/covid19/educationresponse 
University of Houston (2020). Remote teaching check-in survey report. https://fs.uh.edu/api/download.php?docID $=451$

van Sonderen, E., Sanderman, R., \& Coyne, J. C. (2013). Ineffectiveness of reverse wording of questionnaire items: Let's learn from cows in the rain. PLOS One, 8(7), e68967. https://doi.org/10.1371/journal.pone.0068967

Veletsianos, G., \& Kimmons, R. (2020, Apr. 6). What (some) students are saying about the switch to remote teaching and learning. EDUCAUSE Review.

https://er.educause.edu/blogs/2020/4/what-some-students-are-saying-about-the-switch-toremote-teaching-and-learning

Vizcarra, C. (2020, Jun. 24). Communities of practice: Participant survey results. Californians Together. https://www.californianstogether.org/communities-of-practice-participant-surveyresults/

Watermeyer, R., Crick, T., Knight, C. \& Goodall, J. (2020). COVID-19 and digital disruption in UK universities: Afflictions and affordances of emergency online migration. Higher Education. https://doi.org/10.1007/s10734-020-00561-y

World Bank (2020). Tertiary education and COVID-19: Impact and mitigation strategies in Europe and Central Asia.

http://documents1.worldbank.org/curated/en/783451590702592897/COVID-19-Impact-onTertiary-Education-in-Europe-and-Central-Asia.pdf

Xu, D., \& Jaggars, S. S. (2014). Performance gaps between online and face-to-face courses: differences across types of students and academic subject areas. The Journal of Higher Education, 85(5): 632-659. https://doi.org/10.1080/00221546.2014.11777343

Zaccoletti, S., Camacho, A., Correia, N., Aguiar, C., Mason, L., Alves, R. A. \& Daniel, J. R. (2020). Parents' perceptions of student academic motivation during the COVID-19 lockdown: A cross-country comparison. Frontiers in Psychology, 11, 592670. https://doi.org/10.3389/fpsyg.2020.592670

Zhang, W., Wang, Y., Yang, L., \& Wang, C. (2020). Suspending classes without stopping learning: China's education emergency management policy in the COVID-19 outbreak. Journal of Risk and Financial Management, 13(3), 55. https://doi.org/10.3390/jrfm13030055 


\section{Appendix: Supplementary Tables}

\section{Appendix Table 1}

Teachers' engagement in remote teaching scale and teacher coping with remote instruction scale (with the results of exploratory factor analysis; EFA)

\begin{tabular}{|c|c|c|c|}
\hline ( & Short Label & $\begin{array}{c}\text { Factor I } \\
1\end{array}$ & $\begin{array}{r}1 \text { ding } \\
2\end{array}$ \\
\hline $\begin{array}{l}\text { During this epidemic, I have felt that I have to alter not just the } \\
\text { medium and method, but also the content of my classes. }\end{array}$ & modified class content & $.71 *$ & .08 \\
\hline I have had to modify my lesson plans for remote teaching. & modified lesson plans & $.70 *$ & -.11 \\
\hline I have eased the grading scheme. & eased grading & $.65^{*}$ & -.10 \\
\hline $\begin{array}{l}\text { I preferred the 'normal' class format to the remote one I'm } \\
\text { teaching now. }\end{array}$ & \multirow{2}{*}{$\begin{array}{l}\text { preference for F2F } \\
\text { format } \\
\text { reduced possibility to } \\
\text { meet students' needs }\end{array}$} & $.58 *$ & .22 \\
\hline $\begin{array}{l}\text { I feel that remote teaching reduces my possibility to meet students' } \\
\text { individual/special needs. }\end{array}$ & & $.58^{*}$ & .34 \\
\hline I feel disengaged in the remote teaching. & perceived engagement & $.56^{*}$ & .41 \\
\hline I hadn't expected remote teaching to be this hard. & $\begin{array}{l}\text { RT unexpectedly } \\
\text { difficult }\end{array}$ & $.51 *$ & .34 \\
\hline $\begin{array}{l}\text { I haven't been able to fully utilise the potential of remote teaching } \\
\text { because of lack of access to hardware. }\end{array}$ & $\begin{array}{l}\text { lack of hardware } \\
\text { curtailing RT potential }\end{array}$ & .23 & $.60 *$ \\
\hline I feel that I have been left behind by the shift to remote teaching. & feeling left behind & .22 & $.60 *$ \\
\hline $\begin{array}{l}\text { I felt confident in my ability to teach remotely when I was told to } \\
\text { do so. }\end{array}$ & $\begin{array}{l}\text { initial confidence in } \\
\text { RT ability }\end{array}$ & -.29 & $-.53 *$ \\
\hline I have often encountered technical problems with the class. & tech issues & .24 & $.51 *$ \\
\hline I worry about privacy and the security of the software/platform. & cybersecurity anxiety & .14 & $.51 *$ \\
\hline $\begin{array}{l}\text { I have someone to turn to for support if I experience technical } \\
\text { problems with the remote teaching. }\end{array}$ & tech support & .06 & $-.50 *$ \\
\hline $\begin{array}{l}\text { I think that during these times, my teaching does not need to be } \\
\text { perfect. }\end{array}$ & N/A & .30 & -.05 \\
\hline I am willing to devote more time to an online class. & $\mathrm{N} / \mathrm{A}$ & -.07 & -.3 \\
\hline I had full freedom in how to adapt my course(s). & N/A & -.06 & -.37 \\
\hline $\begin{array}{l}\text { My class has been crashed or 'bombed' by unauthorised } \\
\text { participants. }\end{array}$ & N/A & -.02 & .33 \\
\hline $\begin{array}{l}\text { I have been trying to use this opportunity to make my classes } \\
\text { inclusive and accessible to everyone, in line with universal design } \\
\text { (UDL/508 compliant, e.g. accessible for students with disabilities). }\end{array}$ & N/A & .10 & -.26 \\
\hline I have been trying my best to teach well during this time. & N/A & .04 & -.23 \\
\hline
\end{tabular}

* The component loadings $>.50$. Component loadings were obtained using exploratory factor analysis, which allows reducing the data. To extract the factors, we applied the principal components method with orthogonal varimax rotation. As a result, two factors were obtained: Factor 1 measuring teachers' engagement is loaded by 7 items, whereas Factor 2 reflecting teacher coping is composed of 6 items. 
Teachers' Engagement in and Coping with Emergency Remote Instruction during COVID-19-Induced School Closures: A Multinational Contextual Perspective

\section{Appendix Table 2}

Cluster compositions: number and percentage of teachers in each cluster

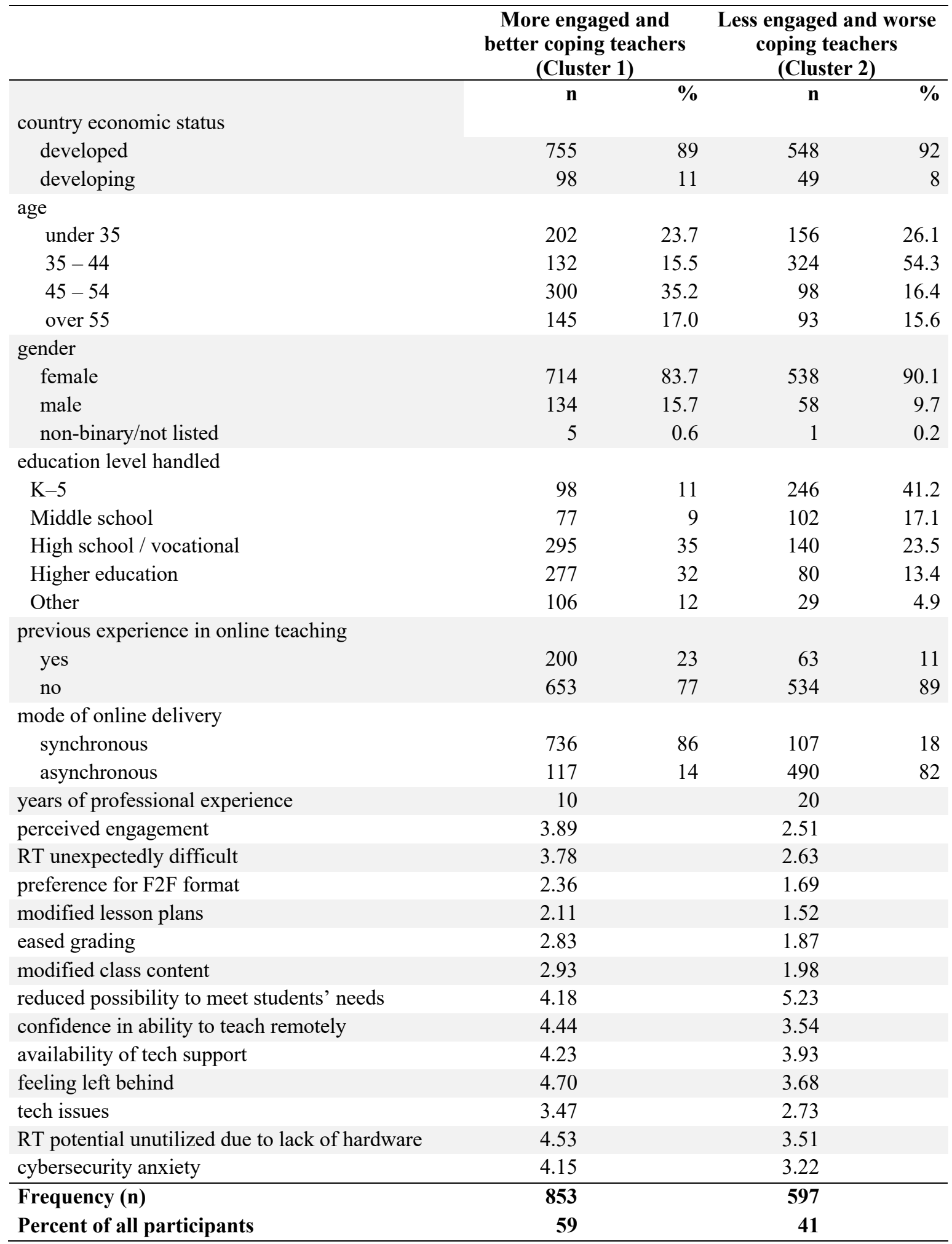

Note: This analysis excludes 37 participants where some data points were missing. 